\title{
Contribution of Oleg K. Tikhomirov to the methodology, theory and experimental practice of psychology
}

\author{
Yuliya D. Babaeva, Natalia B. Berezanskaya, Tatyana V. Kornilova, \\ Igor A. Vasilyev, Aleksandr E. Voiskounsky
}

Lomonosov Moscow State University, Moscow, Russia

\begin{abstract}
The contribution of Oleg K. Tikhomirov (1933-2001), his disciples and representatives of Tikhomirov's school in psychology of thinking is analyzed. Tikhomirov was the initiator of the Personal Meanings Theory of thinking, one of the leading schools of cognitive studies in Russia. Tikhomirov is known outside Russia as well: more than once, he presented his work at international congresses and conferences; his writings have been translated into several European languages. The paper includes brief biographical information about Tikhomirov. The main components of the Personal Meanings Theory are presented, such as the regulative function of (intellectual) emotions during problem solving, the actual genesis of goal-setting, the formation of personal meanings during the processes involved in thinking, and the personality-related determinants of decision making. Tikhomirov's pioneering ideas in the studies of creativity, including jointparticipation in creative activities, are discussed in the paper. In the last section of the paper, Tikhomirov's studies of the impact of information and communication technology on the psychological transformations undergone by adepts of high technologies and technology's effect on their intellectual and communicative activities are discussed; these studies accelerated a new field of research in Russia, namely cyberpsychology or Internet psychology.
\end{abstract}

Keywords: personal meanings theory of thinking, cultural psychology, activity theory, emotions, motivation, goals, goal-setting, creativity, problem solving, computers

\section{Introduction}

Oleg Konstantinovich Tikhomirov was a professor of psychology at Lomonosov Moscow State University, and is considered the true "star" of national psychology. He is widely known for the development of the Personal Meanings Theory of thinking; the basic provisions and development stages of this theory will be analyzed below in detail. With respect to methodology, Tikhomirov relied on cultural- 
historical and activity-based approaches, having creatively developed and synthesized these leading conceptions of Russian national psychology. At the same time, Tikhomirov was an expert in diverse Western psychological theories, first of all, in behavior science and in Jean Piaget's theory.

As a devoted disciple of A.R. Luria and A.N. Leontiev, Tikhomirov, in turn, became the founder and leader of an independent school of thought - one "of the few ... scientific schools headed by the pupils of A.N. Leontiev, A.R. Luria, B.V. Zeigarnik and P.Y. Galperin. This school is considered the pride and hallmark of the psychology faculty of Lomonosov Moscow State University" (Zinchenko, 2008, p. 7). A.A. Matyushkina has analyzed the achievements of Tikhomirov's school and compared them with those of other leading national psychological schools in which creative thinking was studied (Matyushkina, 2008). In a wider historical context, Tikhomirov's works are analyzed in A.N. Zhdan's paper (Zhdan, 2008). According to V.E. Klochko, the Personal Meanings Theory of thinking is connected with post-non-classical prospect (Klochko, 2008), and V.V. Znakov considers it as the theory of overcoming the autonomy of cognitive and existential approaches (Znakov, 2008).

In this paper we'll address the basic theoretical and methodological guidelines which were introduced to world psychology and creatively developed by Tikhomirov, as well as the stages of the development of the Personal Meanings Theory of thinking (Tikhomirov et al., 1999; Babaeva et al., 2008). The scientist's detailed methodological analysis of ideas has also been carried out by T.V. Kornilova (Kornilova, 2008). The fundamental bases of the general psychology were inserted by Tikhomirov into a wide general scientific context and presented in the courses of lectures given by him (Tikhomirov, 1992; Tikhomirov, 2006; Tikhomirov, 2008). Tikhomirov was the one to defend the innovative (at that time) view on mental reflection as having a productive and generating character. It is hard to overestimate Tikhomirov's contribution to the essentials of the psychology of computerization, in which he justified the specificity of human thinking in comparison with the functioning of computer systems and artificial intelligence.

Tikhomirov and representatives of his scientific school investigated reasoning as a gnostic activity: one regulated by emotions, senses, and personality characteristics. The structure of this activity might change due to the dynamics of needs, motives and goals of the subject (Tikhomirov, 1984; Tikhomirov et al., 1999; Babaeva et al., 2008). The investigation of the mechanisms of cognitive activity that included its microstructural analysis and disclosure of its actual genesis was the main task of the Personal Meanings Theory of thinking. The analysis of personality traits in the regulation of thinking, which realized in a new way the idea of the unity of intelligence and affect, became the leading research principle of Tikhomirov's school.

A reconsideration of the leading principles of general psychology and development of the psychological theory of thinking were organically combined in the works of Tikhomirov with the development of such problems as the psychology of computerization and the psychology of decision making (Psychological..., 1987; Tikhomirov, 1992; Kornilova, Tikhomirov, 1990).

This article is urged to present the trajectory of life and scientific way of the founder of the Personal Meanings Theory of thinking, as well as the modern destiny of this theory. It is guided by the previous articles of the authors (Babayeva et 
al., 2008; Kornilova, Voiskounsky, 2007) and materials of the conferences that were devoted to Tikhomirov's $70^{\text {th }}$ anniversary (Creative $\ldots, 2003$ ), his $75^{\text {th }}$ anniversary (Modern ..., 2008) and 80 $0^{\text {th }}$ anniversary (Ideas..., 2013); during the first and the third of these conferences, Tikhomirov's scientific input was analyzed in parallel with the achievements of his contemporary and colleague A.V. Brushlinsky.

\section{Oleg K. Tikhomirov: some biographic details}

Oleg Konstantinovich Tikhomirov was born in Penza (currently in Russia) on April 4, 1933, and at the age of five moved with his parents to Moscow. His mother, Lyubov Stepanovna Tikhomirova, was born 1903 and worked as an economist at an enterprise in Moscow. His father, Konstantin Mikhaylovich Tikhomirov, was born in 1903 and was an engineer as well as a journalist; he died on the battlefield during the Second World War in 1942. In 1951, Tikhomirov entered the philosophical faculty (department of psychology) of Lomonosov Moscow State University (MSU). In 1956 he graduated from MSU and started his postgraduate studies. In 1959 he sucessfully defeated his $\mathrm{PhD}$ thesis under the supervision of A.R. Luria. The subject of his thesis was "The Role of Speech in the Regulation of Movements of PreschoolAged Children". In 1968 Tikhomirov successfully defended his doctoral thesis (in Russia there is a degree higher than a $\mathrm{PhD}$ ) on the "Structure of the Cognitive Activity of a Person". A scientific monograph with a similar name (Tikhomirov, 1969) is well known to Russian psychologists; it has been translated into Polish (Tichomirow, 1976) and partially (chapters IV-VII and X) into German (Bruschlinski, Tichomirow, 1975).

A.N. Leontiev, A.R.Luria, and B. V. Zeigarnik had a huge impact on Tikhomirov's work. The idea of the development of new formations as the main part of the composition of creative thinking was not the only one of the leading topics in the scientific activity of Tikhomirov, but to a certain degree it characterized his own development as a psychologist.

Thanks to A.R. Luria and A.N. Leontiev, Tikhomirov got acquainted with the works of L.S. Vygotsky even before the ban on his publications was removed in 1956, and therefore he was to chose a methodological position on which all his scientific activity was based. Tikhomirov's creative attitude towards the ideas of Vygotsky was keenly noticed by the patriarch of world psychology, Jerome Bruner, in a short comment written in commemoration of Tikhomirov.

On 24 February 2008, Bruner wrote the following note: "Oleg Tikhomirov was a man to admire. He was a man of rigorous scholarship, but at the same time, there was always real imaginativeness in his work. I always thought of him as a scholar who attempted to move our understanding of man and society into modern times, and to relate mental life to the cultural setting in which it took place. He was greatly influenced by Lev Vygotsky and Alexander Romanovich Luria, but one always had the feeling that he was trying to develop their powerful ideas rather than merely accept them. I wish I had had more contact with him! For I always greatly enjoyed our conversations together. Let us honor his memory!"

His introduction of the transformation of the highest mental functions on the basis of the use of essentially new psychological means in an era when many believed in the ultimate computerization of human intellectual activity is one of 
Tikhomirov's contributions to the development of the cultural-historical concept. Bruner mentioned this idea and held it in high esteem. It is necessary to recognize the considerable contribution Tikhomirov and his colleagues made to the development of structure-functional and experiment-genetic analysis methods, as applied to the psychology of thinking. Tikhomirov did much, both in terms of theoretical work and in terms of methodology, to advance the development of the psychological theory of activity, within which the Personal Meanings Theory of thinking was developed. This theory has significantly outstripped cruder rival models in terms of information approach in its genuine understanding of the essence and nature of human thinking.

At a time that saw the liberalization of public life following the end of Stalinism, several new areas of knowledge - in particular, information theory, cybernetics, systems theory and artificial intelligence - evoked the professional interest of Tikhomirov and his fellow students (first and foremost, A.V. Brushlinsky and V.N. Pushkin). In 1970-1971 Tikhomirov completed scientific internships in several universities in the USA and made the personal acquaintance of leading foreign cognitive psychology and artificial intelligence experts (Jerome Bruner, Herbert Simon, Marvin Minsky, and Seymour Papert, among many others). After his return from the USA, Tikhomirov described, with a peculiar sense of humor, the similarities between the academic laboratories in the USA and the Soviet Union, he specifically noted the insufficient level of attention that was devoted to research activity of colleagues at neighboring universities.

As he was not only a brilliant lecturer, but also an excellent academic scientist, Tikhomirov managed a research laboratory at the Institute of Psychology of the Academy of Sciences of the USSR in 1971-1976. He was part-time head of the laboratory: after 1960 Tikhomirov never left the Lomonosov Moscow State University. On July 9, 1990 he was elected the head of the department of general psychology (and was later re-elected for a second term). He raised many disciples, and attracted even more followers among students and professors from other Russian cities who attended Moscow University to upgrade their qualifications. His influence would continue to inspire them for decades.

\section{Emotions in the structure of cognitive activity}

The development of the Personal Meanings Theory of thinking started with a series of studies of the emotional regulation of cognitive activity. The main focus of Tikhomirov and his students was the specifics of human emotions and the identification of their role in the processes of thinking. The application of the activity's approach to the analysis of emotions proved to be valid, and its comparison to information theories of emotions (Breslav, 1977; Psychological..., 1977; Tikhomirov, 1969) allowed researchers to overcome the popular view, according to which emotions, in the course of problem solving, are nothing but hindrances which disrupt the thinking process.

For the first time these special emotions - "intellectual emotions" - were subjected to experimental study. Ancient philosophers had addressed intellectual emotions thus far, however, their positive regulatory role in cognitive activity was demonstrated for the first time by Tikhomirov's school (Tikhomirov, 1969; Vino- 
gradov, 1972; Terekhov, Vasilyev, 1975; Vasilyev, Popluzhny, Tikhomirov, 1980; Artificial..., 1976; Psychological..., 1975; Psychological..., 1979; Vasilyev, 1998). It was shown that intellectual emotions combine and express both the anticipating and heuristic functions; they signal about the generation of new personal meanings as they are created (personal meaning formations) in the course of cognitive activity, and also carry out an integrative function in relation to the new personal meaning formations. As they influence the structures of cognitive activity, such emotions carry out their "delicate" regulation. A.N Leontiev theorized and later proved the idea that emotions play a huge role in the clarification of subjective senses and represent the "sensory fabric of sense" (in Leontiev's psychological theory of activity, human consciousness consists of three different levels: sensory fabric, meanings, and personal meanings).

The theoretical provision of unity of intelligence and affect, formulated by $\mathrm{Vy}$ gotsky, was empirically proven and developed by Tikhomirov's team of researchers. Thus for the first time, it was established that emotional activation inevitably precedes the finding a solution to a problem (which is carrying out a function of goal in the subsequent process of thinking) (Tikhomirov, Vinogradov, 1969). The phenomenon of an "emotional solution" is connected with the emergence of subjective feeling ("the solution is found", even though the idea isn't comprehended yet and isn't issued verbally) and with the change of objective indicators of emotional activation anticipating it. This phenomenon doesn't arise if the solution demands only a mechanical search for alternatives. Emotional experience precedes the objectification of gnostic contradiction and the setting of the goal of cognitive activity, it initiates and directs the search for the logical structure of a contradiction. This phenomenon is called the "emotional detection of a problem". It represents one of the mechanisms of the self-development of thinking and is one of the reasons for the transition of thinking to the status of independent activity.

Another direction of Tikhomirov's research is connected with the identification of certain mechanisms of the emotional regulation of thinking: emotional anchorage, emotional guidance and emotional adjustment. The separate components of a solved task obtain personal meanings and receive corresponding emotional coloring, and emotional anchoring consolidates the personal meanings of the components of cognitive activity. These emotive components define the personal meanings of the specific directions of the search, are used at the solution of the given problem, and are also transferred to the solution of other tasks.

The mechanism of emotional guidance promotes a return to searching for an emotionally anchored component and an association of personal and operational meanings. This emotional adjustment mechanism ensures the changing nature of search operations under the influence of intellectual emotions. The changing nature of search operations means that intellectual emotions accomplish more than just a signaling function; they also achieve an incentive function. The latter manifests itself in the subjective representation of known ways of problem solving or finding new ways to transform a problem, and in case of their absence - in attempts to create new means of finding a solution.

Thus, emotions in the approach justified in Tikhomirov's school act as specific new foundations which are included in the regulation of cognitive activity. Their function is more fully disclosed in the dynamic personal meanings system that is 
formed during the course of cognitive activity. A detailed analysis of the place and role of emotions in thinking is presented in the context of the Personal Meanings Theory of thinking in I.A. Vasilyev 2008 study (Vasilyev, 2008).

\section{Goal setting in cognitive activity}

Goal setting in cognitive activity has received far less attention than it merits, according to A.N. Leontiev (Leontiev, 1975), and as a mental process, it was extensively investigated for the first time in Tikhomirov's school, starting in the 1970s. Goal setting was interpreted as being connected both with the motivational and affective components of the self-regulation of thinking and the formation of cognitive structures (Tikhomirov et al., 1999; Babaeva et al., 2008).

A detailed analysis of the following types and mechanisms of goal setting was executed: the transformation of motives into goal-oriented motives through their acknowledgement; the conversion of by-products of problem solving into goals through their acknowledgement and communication with the motive; the change (reformulation) of the goal if the primary anticipated outcome failed to coincide with one of a variety of goals; the transformation of external requirements into goals by linking them with motives; the extraction of intermediate goals that acted as obstacles; the transition from intermediate to final goals; and the creation of a hierarchy and time sequence of goals (Psychological..., 1977; Tikhomirov, 1993b; Biebrich, 1987). The dependence of the processes of goal setting on the functions and nature of the interaction of voluntary and involuntary mnemonic components at various stages of goal setting was revealed (Znakov, 1978).

The study of the structures, processes, and regulatory aspects of thinking has led to the need to examine the interaction of perceived and unconscious mechanisms that determine the course of the integral process of goal setting (Telegina, 1967; Berezanskaya, 1978; Telegina, Bogdanova, 1980; Tikhomirov, 1969). Nonverbalized anticipations of future outcomes, which prepare a conscious allocation of goals and significantly affect the content and ways of functioning of thinking, were found.

Systematic studies were dedicated to the following subjects: the acceptance of goals on the basis of instructions, intermediate goal setting leading to the achievement of ultimate goals, and undirected goal setting (Psychological..., 1977). A goal's context plays a huge role in the behavior of the abovementioned types of goal setting; this is defined as a summation of objective and subjective conditions of the problem and the goal's acceptance. The partially conscious or subconscious fragments of a goal's context determine in which form and to what extent the goal is accepted, which affects productivity and the dynamics of its implementation. In this process, a significant role is played by the mechanisms of the evaluation of the goal's attainability, which define the set of criteria for the success of its implementation (Berezanskaya, 1978).

The development and functioning of the goal structures of thinking in terms of various forms of communication is reflected in a series of studies of the processes of goal setting in a joint activity (Babaeva et al., 1983; Babaeva et al., 1984; Jakupov, 1985; Artificial..., 1976; Kornilova, Tikhomirov, 1990; Matyushkina, 2001, Psychological..., 1977; Psychological..., 1987). In addition to the objective goals that are 
traditionally considered in the psychology of thinking, a special class of communicative goals which regulate the joint solution of mental problems was introduced. The classification of these goals, the methods of their implementation and the characteristics of their interaction with objective goals was performed (Voiskounsky et al., 1981).

Further studies of goal setting included individual stylistic and strategic analyses (Kornilova, Tikhomirov, 1990; Psychological..., 1987). Diagnostics related to types of intellectual strategies were based on the identification of the dynamics of the hierarchy of goal structures formed by gnostic and pragmatic (Kornilova, 1985), as well as gnostic and communicative goals (Babaeva et al., 1983) and manifested in goal tactics in the study of levels of aspirations (Arestova et al., 1988).

\section{Motivation and thinking}

The development of the principles of the unity of consciousness and activity (S.L. Rubinstein, A.N. Leontiev), the unity of intelligence and affect (L.S. Vygotsky), as well as the categories of personality, motive and meaning in the culturalhistorical and activity approaches opened up opportunities for the development of a new theoretical and methodological approach to understanding the role of motivation in thinking - from the standpoint of the unity of its structural and dynamic, cognitive and meaningful regulation. In addition to those described in the activity, approach, incentive, and meaningful functions of motive, a new - structuring - function has been allocated to the motive function (Gurieva, 1973; Telegina, Bogdanova, 1980; Tikhomirov, Bogdanova, 1983). The structuring function of the motive appears in changes to the structure of an activity, its goal regulation and operational composition.

Obtained experimental data gives clear evidence that the structuring function of the motive manifests in the process of problem solving in the following phenomena:

- actualization of the hidden properties of the objects;

- overcoming of stereotyped beliefs (the phenomena of "psychological inertia" and the "psychological barrier");

- intensifying of the search for a solution;

- going beyond the instructions;

- quest for a non-standard, semantically rich solutions;

- increasing the flexibility of thinking;

- involvement of the processes of imagination, etc.

In traditional psychology, motivational factors are subdivided into two classes: intrinsic and extrinsic motivation. This division is also used in the Personal Meanings Theory of thinking (Tikhomirov, 1984, Tikhomirov, 2006). Intrinsic motivation refers to the specific factors of the genesis of thinking, it meets dynamic cognitive needs and establishes gnostic goals; extrinsic motivation reflects the hierarchy of the underlying motives that are not specific to the regulation of thinking. The demonstration of the effective role of a subject's independent gnostic orientation to identify hidden patterns (Kornilova, 1990, Kornilova, 1986), and the role 
of achievement motivation in the hierarchization of pragmatic and gnostic goals (Kornilova, Chudina, 1990) allowed researchers to move from acknowledging the opposition of intrinsic and extrinsic motivation to identifying their interaction in the development of the goal structures of intellectual strategies. Thus it was shown that different types of motives could manifest a structuring function.

The factors revealed in the study were personal values, personal dispositions and individual style characteristics; these demonstrated their regulatory role in human thinking in experimental and quasi-experimental studies (Kornilova, Budinayte, 1993; Kornilova, Tikhomirov, 1990). Intrinsic motivation is connected to self-regulation and, respectively, to the higher flexibility and productivity of mental activity, and extrinsic motivation is connected to self-control (Vasilyev et al., 2006). The interaction between stable (dispositional) and situational cognitive motivation in terms of macro-and microgenetic analysis has also been studied in experiments in which the solving of chess problems was analyzed (Vasyukova, 1998).

Along with the development of original experimental techniques which set different types and levels of situational motivation, several foreign questionnaires indicating personality and motivational variables were adjusted for Russian samples: "Personal Preferences Questionnaire" by A. Edwards (EPPS), "Personal factors of decision making" (LFR) (Kornilova, 1997; Kornilova, 2003), the questionnaire of J. Kuhl, which indicates the personal characteristics of state- and action orientation (Vasilyev, 2002).

External and internal motivations were distinguished by different criteria their contribution to the structuring of goal hierarchies and the establishment of sense formations. The most predictive approaches were those which made it possible to allocate holistic regulatory profiles, which include, along with the underlying non-specific motivational factors, such properties of self-regulation as rationality and the willingness to take risks, as well as personal tolerance for uncertainty (Vasilyev et al., 2006; Stepanosova, Kornilova, 2006).

The idea of psychological systems, suggested by L.S. Vygotsky, was developed by O.K. Tikhomirov, which resulted in the development of the dynamic personal meanings regulation of thinking. This was reflected in two concepts: that of dynamic personal meaning systems (DPMS) and dynamic regulation systems (DRS).

In the analysis of complex intellectual problems, two types of dynamic personal meanings systems were identified (Vasilyev, 2002; Vasilyev et al., 2006). They differed due to their backgrounds and in terms of how their emotional processes functioned. In the dynamic personal meanings system where there is an internal quality-procedural motive, the emotional component is most intense if the activity is successful. In the dynamic personal meanings system which focuses on external utilitarian motive, the emotional component is of the highest intensity in the case of failure. In the first case, the emotions which occur most often are generated by the course of mental activity and included into its regulation, which largely provides for productive and creative activity. On the contrary, in the second case, mainly negative emotions occur, as a manifestation of internal conflict, when the motive is not consistent with the objective content of activity.

The concept of dynamic regulative systems has been developed in the studies of closed intellectual strategies, in relation to the intellectual and personal mediation of choice (Kornilova, 2005). During the development of a functional and level- 
sensitive conception of the regulation of decision making, the idea of the functional structuring of personal meanings and the cognitive components of the processes of thinking in the expanded (in the "open" problems) and closed (in the "closed" tasks) solution strategies became the leading one (Kornilova, 2003).

As a result of comprehensive research of the multi-level regulation of intellectual strategies, it was found that different dynamic regulation systems are connected not only with the different stages of the process of decision making, but also with different types of regulation of cognitive forecasting. These types are distinguished on the basis of components of the discursive and intuitive preparation of subjective solutions (Stepanosova, Kornilova, 2006). The introduction of dynamic regulatory systems in the context of the relationship between the intellectual and the personal mediation of choice has become an essential step which facilitated the transition from the 'classic' understanding of the structuring function of motive to a new understanding of self-regulation (Kornilova, 2007). Dynamic regulatory systems are the units of self-regulation.

It should also be noted that according to the Personal Meaning Theory of thinking, the creation of motivational and personal meaning, respectively, were not only experimental factors, but also interpretive concepts which were reconstructed based on the specifics of reasoning when solving different types of cognitive tasks. They were presented in the goal and operational interdependence of the processes of hypothesis advancing, anticipating assessments, goal achievement and the phenomena of the selective distortion of thinking (Arestova, 2006; Arestova, 2007; Kornilova, Tikhomirov, 1990).

It was also important to study the personal characteristics of the subject of cognition, among which personal meanings formations were considered to be the leading components of the regulation of thinking.

\section{The creation of personal meaning in cognitive activity}

In studies of the creation of personal meaning, Tikhomirov's scientific school has played a central role (Tikhomirov, 1984). Personal meanings formation was defined as the procedural and structural development of personal meanings in the course of human activity, which integrated the processes of creation and the functioning of the cognitive structures (images, concepts, and knowledge), goals, and the emotional and motivational components of thinking. Vygotsky's statement of the relationship between intelligence and affect, "unity of the affective and intellectual processes", has been understood to mean the unity of the functional development of the cognitive and personal regulation of thinking.

A.N. Leontiev considered thinking as an activity which presented "affective regulation that directly expresses its partiality " (Leontiev, 1967, p. 21). In the activity theory, the concept of a "functional system of integrated emotional and cognitive processes" was generated. According to this belief, emotions can sometimes be "smart", and thinking is intimately linked to the field of personal meanings.

According to Tikhomirov's approach, personal and operational meanings, in their dynamical multi-level interrelation, are included into the role played by personal meanings in the regulation of thinking. Operational meanings can be defined as a special form of psychological reflection which corresponds to the discovery 
of the functional relations of an object in the course of exploratory activity. Operational meanings can change in the course of solving the same problem (Tikhomirov, Terekhov, 1969).

Later on, the concept of dynamic personal meanings system (DPMS) was given new content. It was based on the idea of interaction between personal meanings: "the development of personal meanings of the ultimate goal and intermediate goals, the birth of intentions, as well as the formation of meanings of the elements of the situation and of the entire situation is carried out in unity and with the interaction of cognitive and emotional aspects" (Vasilyev et al., 1980, p. 163). The central structural form of a dynamic personal meanings system is the meaning of the ultimate goal, which goes through a series of stages of development and formation. The meanings of intermediate goals, which determine the selectivity and the regulation of activity which affect the stage where solutions are sought out, are related to the personal meaning of the ultimate goal. Operational meanings develop through verbalization. Along with the analysis of non-verbalized operational meanings (Tikhomirov, 1969), the transfer mechanisms of verbalized operational meanings were also studied (Vasyukova, 2001). Personal meanings develop under the influence of the processes of goal setting (Psychological studies, 1977); goals enrich personal meanings. The processes of-setting goal and the creation of personal meanings cannot be taken into account separately; together they constitute the process of thinking.

In the studies of personal meanings formation in individual and collaborative thinking activity, a special unit - the primary operational meaning of the solution attempt - has been allocated (Matyushkina, 2001; Matyushkina, 2003). It reflects personal meaning in a situation where a person is solving a problem and the detection of contradictions in the objective properties of the task. Under the conditions of individual or joint solution, the attempt to adjust the contradictory properties of the object leads to different representations of primary operational meaning of the solution attempt. Its development is connected with the result of joint cognitive activity - the common foundation of personal meanings structures (Jakupov, 1985). The development of this area of research was disclosed in an article by S.M. Jakupov (Jakupov, 2008).

Personal meanings formation is not an entirely involuntary regulation of mental activity. For an arbitrary meaning formation to find or design new personal meanings as a special task, the ratio of emotionally-intuitive to verbal-reflexive procedures of meanings transformation reflects the specificity of the interconnection of goal regulation and the content of used cultural means. In this case, the interaction of multi-level personal meanings formation mechanisms is not only a regulator, but also a subject matter of thinking. Based on a comparison of subjective and objective parameters, three vectors of the thinking process are identified - a vector of objective meanings, a subject-centered vector and a cultural meaning-oriented sector (reconstruction of the meanings of "the other") (Berezanskaya, 2005; Berezanskaya, Nekrylova, 2003).

The role of personal meanings in mental activity becomes particularly noticeable in the study of the processes of understanding as an existential form of self-discovery when "the human as a person, individual, individuality is not only the subject but also the object of thinking" (Tikhomirov, 1984, p. 201). When he included 
into the subject matter of psychology of thinking the topics of self-knowledge and self-consciousness, and introduced a special term "Self-thinking," O.K. Tikhomirov outlined promising horizons for the development of this concept. This trend was reflected in the article by V.V. Znakov (Znakov, 2008).

\section{Studies of creativity in Tikhomirov's school}

Tikhomirov and his colleagues have made a significant contribution to the problems of the psychology of creativity and creative thinking as its main component. The traditional distinction between productive and reproductive processes was one between creative and conventional thinking patterns (K. Dunker, E. de Bono, J. Guilford, etc.). Tikhomirov suggested that unlike these, the main criterion for any creative activity is indeterminacy of its components and their construction in course of the activity's evolution (Tikhomirov, 1969; Tikhomirov, 1984). According to Tikhomirov: "The specific nature of creative activity is in the generation of new motives, personal meanings, attitudes, goals, and operations in the structure of this activity" (Tikhomirov, 1984, p. 187). The representation of new formations arising in actual genesis at different levels of activity, the stability of these formations and their tendency to generalize (transfer to other forms of activity or to other tasks) defines a "measure of novelty" in the differentiation of creative activity. It is postulated that the stronger the activity transforms the acting person, the more creative this activity is.

The analysis of the psychological changes of subjects of creative activity has become a strategic principle at Tikhomirov's school. This methodology has greatly expanded the traditional subject matter of the psychology of creativity, raising in a new way the focus on the place where creative processes transpire in everyday life and in one's professional activity (Tikhomirov, 1971; Tikhomirov, 1984; Tikhomirov et al., 1982; Psychological... 1975, Tikhomirov, 2006). Thus, according to Tikhomirov's school, the point expressed by A.N. Leontiev about the potentially creative essence of all human activities was concretized: creative activity is determined not only by the development of its subject, but also by the development of the determinants and mechanisms of its regulation.

The formulation of research problems related to the psychology of creativity differed fundamentally in Tikhomirov's school from many other established traditions.

First, conscious and unconscious processes were not opposed but studied in their interaction. The understanding of the types and functions of the unconscious components of creativity, such as non-verbalized exploring operations, the unconscious anticipation of future results, non-verbalized hypotheses, the operational meanings of certain elements of the situation and actions; dynamical systems of semantic structures at various levels, emotional and mindset systems; evaluation systems, including criteria and results of emotional and cognitive evaluations, was significantly expanded (A.G. Azarian, N.B. Berezanskaya, T.G. Bogdanova, A.Y. Bolshunov, I.A. Vasilyev, J.E. Vinogradov, V.E. Klochko, O.M. Krasnoryadtseva, A.A. Matyushkina, E.D. Telegina, V.A. Terekhov).

Thus, Tikhomirov's school significantly altered the meaning of the concept of "intuition", including into it unconscious components of creative activity. It was 
proved that the most important moment of the creative act - an insight that "phenomenologically acts as "enlightenment", or "discretion" of the principle of solution, is the product of a complex orientation and exploratory activity, and this activity itself as well as arising in its course intermediate formations may be hidden from the subject" (Tikhomirov, 1969, p. 162).

Second, a new approach to understanding the role of past experience in creative thinking was proposed. Thus, the ambiguity of dynamics of the use of previous experience in the search for solutions was disclosed (Tikhomirov, Vinogradov, 1969; Znakov, 1978; Azarian, 1989).

Third, the cognitive, emotional and motivational aspects of creativity have been considered in their functional unity. Numerous phenomena, such as "emotional detection of a problem", "emotional decision", "emotional stamping", "emotional guidance" and "emotional correction" which were discovered in Tikhomirov's school, demonstrate the close relationship between "intelligence and affect " in determination of creativity processes.

The application of the experimental hypnotic method, including the suggestion of the image of "the other" person, allowed to vary systematically and trace the influence on the process and results of creative activity of such personal characteristics as identity, position towards the performed activity (e.g., drawing or playing chess), total and intellectual self-esteem, and motivational domain structure (Tikhomirov et al., 1975).

Fourth, creativity acted as a characteristic of the productive processes of decision making, in which alternatives or criteria in the situation of choice are not defined and a person needs to evaluate the admissibility of certain decisions (Kornilova, Tikhomirov, 1990; Kornilova, 2003). In recent experimental formulations, the intellectual potential of a person, in conjunction with a tolerance for uncertainty and deep motivation were considered as predictors of the creativity of productive solutions (Kornilova, Kornilov, 2010; Chumakova, 2009).

Thus, the study of creativity in the works of O.K. Tikhomirov and his students unfolded in the following key areas:

- Disclosure of the mechanisms of interaction of creative and routine components in complex types of intellectual activities (individual and joint activities, in particular, in dialogue with a personal computer);

- Justification of intellectual and personal predictors of creativity;

- Definition of the laws that define the personal determination of creative activity; definition of the limits of their formalization and modeling in artificial intelligence systems;

- Analysis of the conditions for the development of creative aspects of work; identification of the sources of self-development and self-regulation of the creative components of activities for the purpose of improving the educational system and qualified labor.

The Personal Meanings Theory of thinking allows one to make a significant step towards the contemporary understanding of the nature and laws of creativity, which are not reproducible in artificial intelligence systems. Contrasting the results obtained in Tikhomirov's school with traditional issues related to the psychology 
of creativity provides access to new ways of understanding facts that were previously identified and described in other theories. For example, the notion of insight, preconceived in science, was introduced by Gestalt psychology as an instantaneous and spontaneous awareness of the principle of the decision (or the decision itself) was changed. Tikhomirov's school proved that complex interaction took place between the verbalized and non-verbalized components of preparation of the insight before it registered consciously.

\section{Transformation of cognitive structures under the influence of information and communication technology}

The main provisions of the activity theory and cultural-historical approach have been synthesized by Tikhomirov in his analysis of the psychological specificity of solving intellectual problems in the conditions of human and computer interaction. Personal computers and, later on, information technology (IT) were considered to be special psychological means that have the ability to transform the human psyche. Tikhomirov experimentally verified the concept of transforming the psyche using information technology (Artificial..., 1976). One can safely say that during the course of the theoretical and experimental analysis conducted by Tikhomirov on the early (as it is now obvious) stage of development of new technology, the researcher has demonstrated great insight and a keen ability to make scientific predictions. The basic provisions, proposed by him, have been developed in the methodological surveys undertaken by his students (Babaeva, Voiskounsky, 1998; Voiskounsky, 2008; Humanities..., 2000).

In the research, computers do not only mediate mental activity and communication between people (Arestova et al., 1995; Voiskounsky, 1991; Kornilova, Tikhomirov, 1990; Psychological..., 1987; Tikhomirov, Babanin, 1986), but also re-mediate activity, i.e. modify the way it is being mediated as modified ways of performing activity exist (Voiskounsky 2008; Cole, 1997).

As has been repeatedly shown in Tikhomirov's school (particularly in the work of O.N. Arestova, Y.D.Babaeva, L.N. Babanin, I.G. Belavina, N.B. Berezanskaya, A.E. Voiskounsky, I.E. Garber, A.V. Gubanov, L.P. Gurieva, T.V. Kornilova, E.E. Lysenko, N.I. Povyakel, E.D. Telegina, V.A. Terekhov, etc.), in the interaction of a person with the IT, the following leading structural components of the activity are converted: its structure as a whole, its goal structure and individual style characteristics, the content of actions and operations, emotional and personal meanings' regulation, motivational domain. More specifically, studies have shown that when IT is used:

- Methods and procedures of psychological research need to be changed;

- The ratio of creative and routine components, which is traditional for ordinary (not mediated by informational technologies) thinking activity changes;

- Cognitive information technology needs of users develop;

- Content-related, structural, dynamic and procedural aspects of the goal setting process modify; 
- The activity is converted according to the characteristics of the software, including the particular programming language, used by software developers and sometimes by users;

- Personality defense mechanisms manifest, processes of control and critical attitudes are transformed;

- Traditional forms of understanding are modified in dialogue with the knowledge operating systems;

- Phenomena connected to the personification of computers and pieces of software arise.

Further studies of Tikhomirov's school were focused on the analysis of the psychological characteristics of IT activities (especially via the Internet) in cognition, communication, work, and entertainment (including gaming). The specificity of behavior of members of new, previously unknown communities, for example hackers and gamers, was examined; gender aspects of the Internet use were studied; and the psychological nature of the Internet addiction was examined; the phenomena of "presence" in the virtual environment of other individuals and objects that don't exist in real life were identified and classified; the task of expanding the types of giftedness to include specific IT-related endowments was set (see: Architecture..., 2009; Babaeva, Voiskounsky, 2003; Voiskounsky, 2006; Voiskounsky, 2008, Internet addiction ..., 2009).

Lastly it should be noted that in the school of Tikhomirov, the systematic study of computer-mediated human activities was organized for the first time in our country; as a result, many psychologists became aware and genuinely interested in this rapidly expanding field of research.

\section{Conclusion}

Years long theoretical and experimental studies of mental activity performed by Tikhomirov and his students led to the justification of the Personal Meanings Theory of thinking and made Tikhomirov a true leader of a fundamental and original scientific school. The seamless connection of the Personal Meanings Theory of thinking with the activity theory of A.N. Leontiev led to the development and enrichment of the activity approach. This lead to substantial progress in the study of the key components of both the macro- and microstructure of activity. At the same time, Tikhomirov and the representatives of his school creatively applied and developed the most fundamental provisions of mental development theory; those put forward by L.S. Vygotsky.

A course on the "Psychology of Thinking", based on the research conducted by Tikhomirov's school, is systematically offered on an annual basis by the Faculty of Psychology of Moscow State University. Several textbooks: "Psychology. A Course of Lectures" (Tikhomirov, 2006), "Lectures on Psychology" (Tikhomirov, 2008) and "The Psychology of Thinking" (Tikhomirov, 1984), translated into English (Tikhomirov, 1988), were published. Hundreds of students, graduate students, and postdoctoral students have specialized in the psychology of thinking. Moreover, it was estimated that "on average, O.K. Tikhomirov's graduate students and applicants defended their dissertations under his guidance more often than once a year" 
(Zinchenko , 2008, p. 7). Thus, it would be fair to note that more than a decade after the death of its founder and leader, the school of Tikhomirov does not suffer from a lack of students or general interest.

\section{Acknowledgements}

The authors are grateful to Maria Novikova, Ph.D., who translated the paper.

\section{References}

Arestova, O. N. (2006). Psikhologicheskie mekhanizmy strukturiruyuschego vliyaniya motivatsii na myslitelnuyu deyatelnost' [Psychological mechanisms of structuring influence of motivation on thinking activity]. Vestnik Moskovskogo universiteta. Ser.14 Psikhologiya [MoscowUniversity Psychology Bulletin], 3, 3-14; 4, 10-20.

Arestova, O. N. (2007). Diagnostika motivatsionnogo konflikta lichnosti s pomoschyu metoda piktogramm [Diagnostics of personality motivational conflict via pictograms]. Voprosy psikhologii [Issues in Psychology], 2, 161-171.

Arestova, O. N., Babanin, L. N., \& Tikhomirov, O. K. (1988). Komp’yuternyiy analiz motivatsii myslitelnoy deyatelnosti: vozmozhnosti i ogranicheniya [Computer analysis of motivation in thinking activity: possibilities and restrictions]. Voprosy psikhologii [Issues in Psychology], $5,83-91$.

Arestova, O. N., Babanin, L. N., \& Voiskounsky, A. E. (1995). Specifika psikhologicheskikh metodov $v$ usloviyakh primeneniya kompyutera [Specifics of the use of psychological methods with computers]. Moscow University Press.

Arkhitektura virtual'nykh mirov (2009). [Architecture of the virtual worlds]. M. B. Ignatiev, A. V. Nikitin, A. E. Voiskounsky (Eds.). St. Petersburg: Guap Publ.

Azaryan, A. G. (1989) Regulyatsionnoe vliyanie proshlogo opyta sub'ekta na ego tvorcheskuyu deyatel'nost' [The regulatory influence of past experience on creative activity]. (Doctoral dissertation). Moscow.

Babaeva, Yu. D., Berezanskaya, N. B., Vasilyev, I. A., Voiskounsky, A. E., \& Kornilova, T. V. (2008). Smyslovaya teoriya myshleniya [Personal meanings theory of thinking]. Vestnik Moskovskogo universiteta. Seriya 14. Psikhologiya [Moscow University Psychology Bulletin], 2, 26-58.

Babaeva, Yu. D., Voiskounsky, A. E. (1998). Psikhologicheskie posledstviya informatizatsii [Psychological consequences of informatization]. Psikhologicheskiy Zhurnal [Psychological Journal], 19(1), 89-100.

Babaeva, Yu. D., Voiskounsky, A. E. (2003). Odarennyi rebenok za komp'yuterom [Gifted child at the computer]. Moscow: Scanrus Publ.

Babaeva, Yu. D., Voiskounsky, A. E., Kirichenko, T. N., \& Matsneva, N. V. (1983). Tselevaya struktura pri sovmestnom reshenii myslitel'nykh zadach. Soobsh'enie I [The goal-set structure in collective problem solving. Part 1]. Novye issledovaniya $v$ psikhologii [New Research in Psychology], 2, 53-57.

Babaeva, Yu. D., Voiskounsky, A. E., Kirichenko, T. N., \& Matsneva, N. V. (1984). Tselevaya struktura pri sovmestnom reshenii myslitel'nykh zadach. Soobsh'enie II [The goal-set structure in collective problem solving. Part II]. Novye issledovaniya $v$ psikhologii [New Research in Psychology], 1, 61-65.

Berezanskaya, N. B. (1978). Analiz neproizvol'nykh komponentov v strukture tseleobrazovaniya [Involuntary components analysis in the structure of goal formation]. (Doctoral dissertation). Moscow. 
Berezanskaya, N. B. (2005). Kul'turnaya sostavlyayush'aya v modeli kreativnosti [Cultural component in the creativity model]. Ezhegodnik rossiyskogo psikhologicheskogo obshestva. Special'niy vypusk [Russian Psychological Society Yearbook], 1, 49-52.

Berezanskaya, N. B., Nekrylova, N. V. (2003). Ponimanie proizvedeniya iskusstva kak forma smys lovogo myshleniya [Artworks understanding as a form of personal meaning thinking]. Tvorcheskoe nasledie A. V. Brushlinskogo i O. K. Tikhomirova i sovremennaya psikhologiya myshleniya ( $k$ 70letiyu so dnya rozhdeniya). Tezisy dokladov nauchnoy konferentsii. V. V. Znakov, T. V. Kornilova (Eds.). (pp. 345-348). Moscow: Institute of Psychology, Russian Academy of Sciences Publ.

Biebrich, R. R. (1987). Issledovanie vidov tseleobrazovaniya [Study of goal formation types]. O. K. Tikhomirov (Ed.). Kishinev: Shtiinza Publ.

Breslav, G. M. (1977). Kriticheskiy analiz informatsionno-kiberneticheskogo podkhoda k issledovaniyu emotsiy: O putyakh izucheniya prirody emotsiy. [Critical analysis of informationcybernetic approach to emotions study: On the directions of the study of the nature of emotions)]. (Doctoral dissertation). Moscow.

Chumakova, M. A. (2009). Motivatsiya i prakticheskiy intellekt $\mathrm{v}$ funktsional'noy regulyatsii ratsional'nogo vybora [Motivation and practical intelligence in the functional regulation of rational choice]. Vestnik Tambovskogo gosudarstvennogo universiteta. Seriya Gumanitarnye Nauki [Tambov State University Bulletin. Humanities], 9(77), 264-269.

Cole, M. (1997). Kul'turno-istoricheskaya psikhologiya [Cultural psychology]. Moscow: CogitoCentre Publ.

Gumanitarnye issledovaniya $v$ Internete [Humanities research on the Internet] (2000). A. E. Voiskounsky (Ed.). Moscow: Mozhaisk-Terra Publ.

Gurieva, L. P. (1973). Umstvennaya deyatel'nost'v usloviyakh avtomatizatsii [Thinking activity and computers]. (Doctoral dissertation). Moscow.

Idei O. K. Tikhomirova i A. V. Brushlinskogo ifundamentalnye problemy psikhologii ( $k$ 80-letiyu so dnya rozhdeniya) [Tikhomirov and Brushlinskiy's ideas and fundamental psychology problems] (2013). Materialyi Vserossiyskoy nauchnoy conferentsii (s inostrannym uchastiem). Moscow University Press.

Internetzavisimost': psikhologicheskaya priroda i dinamika razvitiya [Internet addiction: the psychological nature and dynamics of development] (2009). A.E. Voiskounsky (Ed.). Moscow: Akropol Publ.

«Iskusstvennyy intellekt» I Psikhologiya ["Artifitial Intelligence" and psychology] (1976). O.K. Tikhomirov (Ed.). Moscow: Nauka Publ.

Jakupov, S. M. (1985). Tseleobrazovanie v sovmestnoy deyatel'nosti [Goal formation in the collective activity]. (Doctoral dissertation). Moscow.

Jakupov, S. M. (2008). Razvitie smyslovoy teorii myshleniya v kontseptsii sovmestno-dialo gicheskoy poznavatel'noy deyatel'nosti [The development of the personal meanings theory of thinking within the conception of the joint dialogic cognitive activity]. Vestnik Moskovskogo universiteta. Seriya 14. Psikhologiya [Moscow University Psychology Bulletin], 2, $180-188$.

Klochko, V. E. (2008). Smyslovaya teoriya myshleniya v transspektive stanovleniya psikhologicheskogo poznaniya: epistemologicheskyi analiz [Transspective formation of the personal meanings theory of thinking: epistemologic analysis]. Vestnik Moskovskogo universiteta. Seriya 14. Psikhologiya [Moscow University Psychology Bulletin], 2, 87-101.

Kornilova, T. V. (1985). O tipakh intellektual'nykh strategiy [On the types of intellectual strategies]. Vestnik Moskovskogo universiteta. Ser. 14. Psikhologiya [Moscow University Psychology Bulletin], 3, 11-24. 
Kornilova, T. V. (1990). Poznavatel'naya aktivnost' pri reshenii diskursivnoy zadachi v kompyuterizovannom eksperimente [Cognitive activity during the discursive problem solving in the computerized experiment]. Voprosy psikhologii [Issues in Psychology], 5, 141143.

Kornilova, T. V. (1997). Diagnostika motivatsii i gotovnosti $k$ risku [Diagnostics of motivation and preparedness to take risks]. Moscow: Institute of Psychology, Russian Academy of Sciences Publ.

Kornilova, T. V. (2003). Psikhologiya riska i prinyatiya resheniy [Psychology of risk and decision making]. Moscow: Aspect-Press Publ.

Kornilova, T. V. (2005). Metodologicheskie problemy psikhologii prinyatiya resheniy [Methodological problems of the decision-making psychology]. Psikhologicheskiy zhurnal [Psychological Journal], 26(1), 3-20.

Kornilova, T. V. (2007). Samoregulyatsiya i lichnostno-motivatsionnaya regulyatsiya [Self-regulation and personal-motivational regulation]. In V.I. Morosanova (Ed.) Subjekt i lichnost'v psikhologii samoregulyatsii (pp.181-194). Moscow \& Stavropol'.

Kornilova, T. V. (2008). Metodologicheskie problemi psikhologii v trudakh O.K. Tikhomirova i ego shkoly [Methodological problems of psychology in the writings of Tikhomirov and his school]. Vestnik Moskovskogo universiteta. Seriya 14. Psikhologiya [Moscow University Psychology Bulletin], 2, 59-73.

Kornilova, T. V., Budinaite, G. (1993). Lichnostnye tsennosti i lichnostnye predpochteniya subekta [Personal values and personalized preferences]. Voprosy psikhologii [Issues in Psychology], 5, 99-105.

Kornilova, T. V., Voiskounsky, A. E. (2007). Oleg Konstantinovich Tikhomirov. Sozdatel' shkoly myshleniya v Moskovskom universitete [Oleg K. Tikhomirov. The initiator of the school of thinking at the Moscow University]. In V.V. Rubcov, M.G. Yaroshevsky (Eds.) Vydayusch'iesya psikhologi Moskvy. (pp. 425-432). Moscow.

Kornilova, T. V. (1986). Myshlenie, oposredstvovannoe dannymi EVM [Thinking mediated by computer data]. Voprosy psikhologii [Issues in Psychology], 6, 123-130.

Kornilova, T. V., Tikhomirov, O. K. (1990). Prinyatie intellektual'nykh resheniy v dialoge s komp'yu terom [Making intelligent decisions in dialogue with a computer]. Moscow University Press.

Kornilova, T. V., Chudina, T. V. (1990). Lichnostnye i situatsionnye faktory prinyatiya resheniy v usloviyakh dialoga s EVM [Personal and situational decision-making factors in a dialogue with a computer]. Psikhologicheskiy zhurnal [Psychological Journal], 18(4), 32-37.

Leontiev, A. N. (1967). O nekotorykh perspektivnykh problemakh sovetskoy psikhologii [On some perspective problems in Soviet psychology]. Voprosy psikhologii [Issues in Psychology], $6,7-22$.

Leontiev, A. N. (1975). Deyatel'nost'. Soznanie. Lichnost' [Activity. Consciousness. Personality]. Moscow: Politizdat Publ.

Matyushkina, A. A. (2001). Sravnitel'nyi analiz smysloobrazovaniya v individual'nom i gruppovom myshlenii [Personal meanings formation: a comparative analysis in individual and group thinking]. (Doctoral dissertation). Moscow.

Matyushkina, A. A. (2003). Reshenie problemy kak poisk smyslov [Problem solving as a search for personal meanings]. Moscow.

Matyushkina, A. A. (2008). Tvorcheskoe myshlenie kak predmet issledovaniya v otechestvennoy psikhologii: nauchnye shkoly O.K. Tikhomirova, A.M. Matyushkina, Ya.A. Ponomareva [Creative thinking as a study object in Russian psychology: scientific schools of O.K. Tikhomirov, A.M. Matyushkin, Ya.A. Ponomarev]. Vestnik Moskovskogo universiteta. Seriya 14. Psikhologiya [Moscow University Psychology Bulletin], 2, 102-112. 
Psikhologicheskie issledovaniya intellektual'noy deyatel'nosti [Psychological studies of intellectual activity]. (1979). O. K. Tikhomirov (Ed.). Moscow: Nauka Publ.

Psikhologicheskie issledovaniya tvorcheskoy deyatelnosti [Psychological studies of creativity]. (1975). O. K. Tikhomirov (Ed.). Moscow: Nauka Publ.

Psikhologicheskie mekhanizmy tseleobrazovaniya [Goal-formation psychological mechanisms]. (1977). O. K. Tikhomirov (Ed.). Moscow: Nauka Publ.

Psikhologicheskie problemy avtomatizatsii nauchnoissledovatel'skoy deyatel'nosti [Psychological problems of computerized research]. (1987). O. K. Tikhomirov, M.G. Yaroshevsky (Eds.). Moscow: Nauka Publ.

Salikhova, N. R. (2005). Tipy smysloobrazovaniya $v$ kontekste lichnostnykh tsennostey [Types of meaning formation in the personal values context]. Kazan' University Publ.

Sovremennaya psikhologiya myshleniya: smysl v poznanii [Modern psychology of thinking: meaning in the cognition]. (2008). Tezisi dokladov nauchnoy konferentsii, posvyaschennoy 75-letiyu so dnya rozhdeniya O.K. Tikhomirova. Yu.P. Zinchenko, A.E. Voiskounsky, \& T.V. Kornilova (Eds.). Moscow: Smysl Publ.

Stepanosova, O. V., Kornilova, T. V. (2006). Motivatsiya i intuitsiya v regulyatsii verbal'nykh prognozov pri prinyatii resheniy [Motivation and intuition in the regulation of verbal prognoses in the process of decision making]. Psikhologicheskiy zhurnal [Psychological Journal], 27(2), 60-68.

Telegina, E. D. (1967). Psikhologicheskiy analiz evristik cheloveka [Psychological analysis of human heuristics]. (Doctoral dissertation). Moscow.

Telegina, E. D., Bogdanova, T. G. (1980). O vliyanii znachimosti motiva na protsess resheniya myslitel'nykh zadach [On the influence of motive significance on problem solving]. Voprosy psikhologii [Issues in Psychology], 1, 121-124.

Terekhov, V. A., Vasilyev, I. A. (1975). K kharakteristike protsessov tseleobrazovaniya pri reshenii myslitel'nykh zadach [To the characterization of the goal-formation processes in problem solving]. Voprosy psikhologii [Issues in Psychology], 1, 12-21.

Tikhomirov, O. K. (1969). Struktura myslitel'noy deyatel'nosti cheloveka [The structure of human thinking activity]. Moscow University Press

Tikhomirov, O. K. (1971). Evristicheskoe programmirovanie i psikhologiya tvorcheskogo myshleniya [Heuristic programming and the psychology of creative thinking]. In M.G. Yaroshevsky (Ed.). Problemy nauchnogo tvorchestva v sovremennoy psikhologii. (pp. 265-307). Moscow: Nauka Publ.

Tikhomirov, O. K. (1984). Psikhologiya myshleniya. [Psychology of thinking: Textbook]. Moscow University Press.

Tikhomirov, O. K. (1992). Ponyatiya i printsipy obschey psikhologii [Concepts and principles of general psychology]. Moscow University Press.

Tikhomirov, O. K. (1993a). Informatsionnyi vek i teoriya L.S. Vygotskogo [The information age and the L.S. Vygotsky' theory]. Psikhologicheskiy zhurnal [Psychological Journal], 14(1), 114-119.

Tikhomirov, O. K. (1993b). Teoriya deyatel'nosti, izmenennoy informatsionnoy tekhnologiey [The theory of activity modified by information technology]. Vestnik Moskovskogo universiteta. Ser. 14. Psikhologiya [Moscow University Psychology Bulletin], 3, 30-40.

Tikhomirov, O. K. (2006). Psikhologiya. Uchebnik [Psychology. Textbook]. O.V. Gordeeva (Ed.). Moscow.

Tikhomirov, O. K. (2008). Lektsii po psikhologii [Lectures on psychology]. O.V. Gordeeva (Ed.). Moscow.

Tikhomirov, O. K., Babaeva, Yu. D., Berezanskaya, N. B., Vasilyev, I. A., \& Voiskounsky, A. E. (1999). Razvitie deyatel'nostnogo podkhoda v psikhologii myshleniya [The activity approach 
development in psychology of thinking]. In A.E.Voiskounsky, A.N.Zhdan, O.K.Tikhomirov (eds.). Traditsii i perspektivy deyatel'nostnogo podkhoda $v$ psikhologii: shkola A.N.Leontieva. (pp. 191-234). Moscow University Press.

Tikhomirov, O. K., Babanin, L. N. (1986). EVM i novye problemy psikhologii [Computers and new problems in psychology]. Moscow University Press.

Tikhomirov, O. K., Belavina, I. G., Berezanskaya, N. B., Bogdanova, T. G., \& Vasilyev, I. A. (1982).

Psikhologiya i praktika avtomatizatsii proektirovaniya EVM [Psychology and practice of computerized design of computers]. Psikhologicheskiy zhurnal [Psychological Journal], 3(5), $39-53$.

Tikhomirov, O. K., Bogdanova, T. G. (1983). Issledovanie strukturiruyusch'ey funktsii motiva [The study of the structuring function of motives]. Psikhologicheskiy zhurnal [Psychological Journal], 4(6), 54-61.

Tikhomirov, O. K., Vinogradov, Yu. E. (1969). Emotsii v funktsii evristik [Emotions in heuristics function]. Psikhologicheskie issledovaniya [Psychological Research], 1, 3-24.

Tikhomirov, O. K., Raykov, V. L., \& Berezanskaya, N. B. (1975). Ob odnom podkhode k issledovaniyu myshleniya kak deyatel'nosti lichnosti [Approach to the study of thinking as an activity of a person]. Psikhologicheskie issledovaniya tvorcheskoy deyatel'nosti. O.K.Tikhomirov (Ed.). Moscow: Nauka Publ.

Tikhomirov, O. K., Terekhov, V. A. (1969). Znachenie i smysl v processe resheniya myslitel'noy zadachi [Meaning and personal meaning in problem solving process]. Voprosy psikhologii [Issues in Psychology], 4, 66-84.

Tvorcheskoe nasledie A.V. Brushlinskogo i O.K. Tikhomirova i sovremennaya psikhologiya mysh leniya ( $k$ 70letiyu so dnya rozhdeniya). Tezisy dokladov nauchnoy konferentsii [A. V. Brushlinsky's and O. K. Tihomirov's creative heritage and modern psychology of thinking (to the 70th anniversary)] (2003). Moscow: Institute of Psychology, Russian Academy of Sciences Publ.

Vasilyev, I.A. (1998). Rol' intellektual'nikh emotsiy v regulyatsii myslitel'noy deyatel'nosti [The role of intellectual emotions in the regulation of thinking activity]. Psikhologicheskiy zhurnal [Psychological Journal], 4, 49-60.

Vasilyev, I.A. (2002). Strategicheskoe myshlenie v slozhnykh oblastyakh real'nosti [Strategic thinking in complex areas of reality]. Uchenye zapiski kafedrt obschey psikhologii MGU im. M.V. Lomonosova [Proceedings of Moscow University General Psychology Chair], 1, 102118.

Vasilyev, I.A. (2008). Mesto i rol' emotsiy v psikhologicheskoy sisteme [Position and role of emotions in a psychological system]. Vestnik Moskovskogo universiteta. Seriya 14. Psikhologiya [Moscow University Psychology Bulletin], 2, 113-127.

Vasilyev, I. A., Popluzhny, V. L., \& Tikhomirov, O. K. (1980). Emotsii i myshlenie [Emotions and Thinking]. Moscow University Press.

Vasilyev, I. A., Mitina, O. V., \& Kobanov, V. V. (2006). Vliyanie razlichnykh tipov motivatsii i samoupravleniya lichnosti na produktivnost' myslitel'noy deyatel'nosti [Impact of different types of motivation and self-management on the productiveness of thinking activity]. Psikho logicheskiy zhurnal [Psychological Journal], 27(4), 38-49.

Vasyukova, E. E. (1998). Tvorcheskaya deyatel'nost' shakhmatista v usloviyakh ispol'zovaniya informatsionno-poiskovykh shakhmatnykh sistem [Chessplayer creative activity with information retrieval chess systems usage]. Psikhologicheskiy zhurnal [Psychological Journal], 19(3), 91-103.

Vasyukova, E. E. (2001). Verbalizovannye operatsional'nye smysly i ikh razvitie v protsesse prinyatiya resheniya (na materiale vybora luchshego khoda $\mathrm{v}$ shakhmatnoy pozitsii) [Verbalized 
operational meanings development in decision-making (based on the best move selection in a chess position)]. Psikhologicheskiy zhurnal [Psychological Journal], 22(4), 30-41.

Vinogradov, Yu. E. (1972). Emotsional'naya aktivatsiya v strukture myslitel'noy deyatel'nosti cheloveka [Emotional activation in the structure of human thinking]. (Doctoral dissertation). Moscow.

Voiskounsky, A. E. (1991). Rechevaya deyatel'nost' v khode komp'yuternykh konferentsiy [Speech activity during computer conferences]. Voprosy psikhologii [Issues in Psychology], $6,142-147$.

Voiskounsky, A. E. (2006). Issledovaniya v oblasti psikhologii komp'yuterizatsii: istoriya i aktual'noe sostoyanie [Studies in psychology of computerization: history and current state]. Natsional'niy psikhologicheskiy zhurnal [National Psychological Journal], 1, 58-62.

Voiskounsky, A. E. (2008). Ot psikhologii komp'yuterizatsii k psikhologii Interneta [From psychology of computerization to Internet psychology]. Vestnik Moskovskogo universiteta. Seriya 14. Psikhologiya [Moscow University Psychology Bulletin], 2, 140-153.

Voiskounsky, A. E., Shmerling, D. S., \& Yaglom, M. A. (1981). Klassifikatsiya rechevykh vyskazyvaniy pri sovmestnom reshenii myslitel'nykh zadach [Speech utterances classification during the collective problem solving]. Vestnik Moskovskogo universiteta. Ser. 14. Psikhologiya [Moscow University Psychology Bulletin], 3, 3-12.

Zhdan, A. N. (2008). Tvorchestvo O. K. Tikhomirova: istoriko-psikhologicheskiy vzglyad [O.K. Tikhomirov's creative activity: historical-psychological view]. Vestnik Moskovskogo universiteta. Seriya 14. Psikhologiya [Moscow University Psychology Bulletin], 2, 9-25.

Zinchenko, Yu. P. (2008). Oleg Konstantinovich Tikhomirov - professor fakul'teta psikhologii Moskovskogo universiteta [Oleg K. Tikhomirov - Professor of the Psychology Department, Moscow University]. Vestnik Moskovskogo universiteta. Seriya 14. Psikhologiya [Moscow University Psychology Bulletin], 2, 4-8.

Znakov, V. V. (1978). Mnemicheskie komponenty tseleobrazovaniya [Mnemic components of goal formation]. (Doctoral dissertation). Moscow.

Znakov, V. V. (2008). Myshlenie, samosoznanie i samoponimanie [Thinking, self-conscience and self-understanding]. Vestnik Moskovskogo universiteta. Seriya 14. Psikhologiya [Moscow University Psychology Bulletin], 2, 74-86.

Received: 25 September 2013

Accepted: 01 November 2013

Available online: 15 December 2013 